\title{
What determines bank CDS spreads? Evidence from European and US banks
}

Danilo Drago

Department of Economics, University of Calabria, Rende CS, Italy

Caterina Di Tommaso

Department of Economics, University of Calabria, Rende CS, Italy

John Thornton (Corresponding author)

The Business School, Bangor University, Bangor LL57 2DG, UK

\begin{abstract}
We examine the determinants of CDS spreads for a sample of European and US banks. The key balance sheet determinants are leverage, asset quality, funding stability, and bank size, and the key market determinants are equity returns, the term structure of interest rates and bank-specific and host country sovereign credit risk. Our results would appear to con- firm the applicability of Merton (1974)-type models extended to include market variables to the understanding of bank credit risk.
\end{abstract}

Keywords: Credit default swaps, Bank credit risk, Balance sheet variables, Market variables

JEL codes: E43 G1 G12 G13 


\section{What determines bank CDS spreads? Evidence from European and US banks}

\section{Introduction}

In recent years there have been at least three important developments in empirical applications of the Merton (1974) approach to modelling credit default risk. First, structural or balance sheet determinants were supplemented with market variables because of dissatisfaction with the explanatory power of structural models (the so-called "credit spread puzzle"). Second, following the development (and subsequent rapid growth) of the market for credit derivatives in the early 1990s, credit default swap (CDS) data were incorporated in place of bond yields in studies of credit risk. $^{2}$ This offered several advantages, including a more direct measure of credit risk (Hull et al., 2004), a more rapid price-discovery process (Blanco et al., (2005), and less distortion from taxes and the liquidity premium (e.g., Longstaff et al., 2005; Chen et al., 2007; Fabozzi et al., 2007). Third, it was accepted that Merton-type models could also be used to study credit risk in the banking sector. Early empirical studies were focused on the nonbank corporate sector because it was assumed that banks' asset-liability structure and regulatory obligations would limit the variation in leverage ratios and exaggerate the credit-spread puzzle. However, leverage and capital ratios have varied across banks and over time reflecting different preferences as to risk taking (Tian et al., 2013; Kalemli-Ozcan et al., 2012; Brewer et al., 2008; Diamond and Rajan, 2000). This combined with an extensive theoretical literature showing that changes in bank leverage can propagate adverse shocks to the real sector (e.g., Kiyotaki and Moore, 1997; Bernanke and Gertler,

\footnotetext{
${ }^{1}$ The "credit spread puzzle" was the term given to the empirical finding that structural variables appeared to explain only a moderate portion of credit spread variability (see, e.g., Duffee, 1998; Driessen 2005).

${ }^{2}$ Benkert (2004) derived the applicability of Merton's (1974) structural theory to the CDS market.
} 
1995), and that systemic banking crises remain relatively frequent and costly (Laeven and Valencia, 2012), has encouraged several studies using CDS spreads to model bank credit risk (e.g., Samaniego-Medina et al., 2016; Hasan et al., 2014; Annaert et al., 2013; Chiaramonte and Casu, 2013; Alter and Schüler, 2012). In this short paper, we contribute to the literature on the determinants of bank CDS spreads in two ways. First, by focusing on the banking sector and testing the impact of structural and market variables we extend what remains a limited banking literature on the topic. Second, we present results from a sample that offers greater time (2007-2016) and cross-country (USA, "core" euro area countries, "non-core" or periphery euro area countries, and non-euro adopting European countries) variation than has been typical in the other banking studies. $^{3}$

\section{Methodology, data and descriptive statistics}

Our baseline model is typical of the CDS spreads literature:

$C D S_{i t+1 w e e k}=\propto+\beta X_{i t}+\gamma Z_{i t}+\varepsilon_{i t}$

Where $C D S_{i t+1 \text { week }}$ is a bank's CDS spread (in basis points) one week after the end of each quarter, $X_{i t}$ is a vector of bank balance sheet variables, $Z_{i t}$ is a vector of market variables, and $i$, and $t$ denote banks, country and time period, respectively.

\footnotetext{
${ }^{3}$ For our purposes, the "core" euro area countries are Austria, Belgium, France, Germany, and the Netherlands; the "non-core" euro area countries are Greece, Italy, Portugal, Spain, and Ireland; and the non-euro adopting European countries are Denmark, Sweden, Switzerland and the United Kingdom.
} 
Five-year CDS spread data on senior CDS contracts was chosen because it is the most liquid of the spread tenors and the CDS contracts are all quoted in U.S. dollars to avoid exchange rate challenges. The data are recorded in percentages, so a regression coefficient of 1.50 represents $1.50 \%$ or 150 bps. We focus on spreads one week after the end of the quarter on the assumption that bank balance sheet data are not immediately available at the end of the quarter. The balance sheet and market variables are commonly used in the credit risk literature. The balance sheet variables in $X_{i t}$ include: the bank capital adequacy ratio, which captures a bank's capability to absorb losses and cope with exogenous shocks; leverage, which captures bank indebtedness and risk appetite; nonperforming loans and loan provisioning, which give an indication of bank asset quality; bank size, to capture the ability to diversify risk through economies of scope, and because market participants may deem large banks too big to fail; and the ratio of retail deposits to total liabilities, because retail deposits are a relatively stable source of funding. A priori, we expect more capital, bank size, and retail deposit funding to reduce CDS spreads, and more leverage, nonperforming loans and loan provisions to increase spreads. The market variables included in $Z_{i t}$ are: stock market returns, to capture the general business climate, which is assumed to be better if stock returns are higher; the volatility of stock prices, to capture the uncertainty about economic prospects, which is assumed to be greater if stocks are more volatile; the term structure of interest rates, which is also an indicator of economic prospects and with improvement suggested by an upward sloping yield curve; the "risk free" interest rate (government bond yield), because it is an indicator of sovereign risk; each bank's credit risk rating; and the bank host country sovereign credit risk rating, because of bank- sovereign linkages through bank holdings of government debt and the potential for troubled banks to burden the public finances. A priori, we expect higher stock market returns, an upward sloping yield curve, and a higher sovereign and bank credit risk rating 
to be associated with a reduction in spreads, and more volatile stock returns and a higher risk-free interest rate to be associated with an increase in spreads. The estimates also include a dummy variable for the onset of financial crisis in the US. ${ }^{4}$ The data are quarterly for the period Q1 2007 to Q1 2016 and include 54 banks from European 14 countries and 9 large US banks. The sources of the data, construction of the variables, and the expected signs on the estimated coefficients are set out in Table 1.

\section{Empirical results}

Figure 1 shows quarterly developments in CDS spreads during the sample period for all banks and by geographic location. CDS spreads of euro-periphery banks moved sharply higher than those of banks in the other countries from 2009 and remained well above them for the rest of the sample period. ${ }^{5}$ Bank spreads in the other countries for the most part moved closely together and were lowest for banks in non-euro adopting countries and the US. Summary statistics for the key variables are shown in Table 2. The most striking differences across countries are that US banks were substantially less leveraged than European banks, the poorer loan quality of euro-periphery banks, and the lower sovereign credit rating of euro-periphery countries. Correlation coefficients between the dependent variables (not reported) ranged from -0.37 to 0.39 , suggesting that multicollinearity is unlikely to be a problem for the regression estimates.

\footnotetext{
${ }^{4}$ Alternative estimates (available on request) that included a crisis dummy for the outbreak of the European sovereign debt crisis in place of the dummy for the onset of the US crisis yielded virtually identical results to those reported in Section 4.

${ }^{5}$ Developments in CDS spreads in the euro-periphery countries were driven mainly by Greek banks for which the spread averaged 965.40 basis points over the sample period and reached 2378.97 basis points in late 2011 .
} 
Estimates from panel regressions with time and bank fixed effects are reported in Table 3. Column 1 reports results from the baseline regression where the dependent variable is $C D S_{i t+1 w e e k}$. Bank leverage, loan quality, bank size, and funding structure are the key balance sheet factors explaining CDS spreads. More specifically, credit risk appears to be higher for more leveraged banks, and for banks with higher non-performing loans; and it is lower for larger banks and for banks that fund their assets through a larger proportion of retail deposits. Bank capital appears to play no direct role in the determination of spreads, which may be indicative of the misleading nature of capital adequacy ratios given that they are subject to bank manipulation through the management of risk weights (e.g., Admati and Hellwig, 2013). All of the market variables are statistically significant with the anticipated sign on the estimated coefficients with the exception of the risk-free interest rate, which is not statistically significant. Specifically, bank CDS spreads narrow in response to improvements in the stock market, an upward sloping yield curve, and upgrades in sovereign and bank-specific credit risk ratings, and widen as stock market volatility increases signaling an improvement in economic prospects, and widen as a county's sovereign credit rating deteriorates, probably reflecting the sovereign-bank public debt linkages Not surprisingly, the onset of the US financial crisis is also associated with a widening of CDS spreads. We decompose the share of the explained variance of the regression into contributions by three groups of regressors: balance sheet variables, market variables, and the crisis dummy, which we report in the final three rows of Table 3. ${ }^{6}$ The explanatory power of the balance sheet and market variable groups is broadly equivalent

${ }^{6}$ We measure the marginal contribution $M C_{k}$ of the three groups of variables as: $M C_{k}=\frac{R^{2}-R_{k}^{2}}{\sum_{k-1}^{3}\left(R^{2}-R_{k}^{2}\right)}$ where $R_{k}^{2}$ is the explanatory power of the regression using only one of the three groups of variables and $R^{2}$ is the explanatory power of the complete model (Annaert et al. 2012). 
( $20 \%$ and $22 \%$, respectively) but both are dominated in their impact on CDS spreads by the onset of the US financial crisis (explaining $58 \%$ of the variance).

For robustness, in columns 2 and 3 of Table 3 we report results under different assumptions about the timeliness of bank balance sheet data. In column 2, we assume that balance sheet data are immediately available to market participants and re-specify the dependent variable as $C D S_{i t}$. In column 3, we assume a longer time period before balance sheet information is available and respecify the dependent variable as $C D S_{i t}+2$ weeks. In both cases the results largely confirm our baseline findings, though there is some information loss on the importance of funding structure, the term structure of interest rates, and sovereign risk rating when $C D S_{i t}$ is the dependent variable.

Table 4 reports results from estimating our baseline equation separately for banks by different groups of European countries - "core" euro countries, euro periphery countries, non-euro adoption EU countries, and the US. There appear to have been important differences in the determinants of spreads across (groups of) countries. The baseline model fits well for US banks for which all the balance sheet variables are statistically significant and of the anticipated signs, including the capital-asset ratio, an increase in which is associated with a narrowing of spreads, as would be expected. All the market variables are statistically significant with the exception of the risk free interest rate. ${ }^{7}$ The results for the other country groups are mixed: funding structure and current and prospective business conditions appear to dominate spreads in core euro country banks; leverage, asset quality, bank size, and bank-specific and sovereign risk ratings are key drivers of CDS

\footnotetext{
7 The sovereign risk rating variable was excluded from the estimate of CDS spreads for US banks because of insufficient observations.
} 
spreads in euro-periphery country banks, and current and prospective business condition are key drivers of spreads of banks in non-euro adopting European countries.

\section{Conclusions}

In this paper, we examined the determinants of bank CDS spreads for a sample of European and US banks during 2007-2016, a period dominated by financial crisis. Although experience with bank spreads appears to differ across countries, our key results suggest that less capital, greater leverage, poor asset quality, funding instability, a weak current and prospective business environment, and a low bank-specific credit rating are all associated with a widening of bank CDS spreads. In addition, bank size and sovereign risk rating also appear to be important determinants of CDS spreads. In the former case, this might reflect economies of scope and/or creditors perception that large banks are too big to fail; in the latter case, it likely reflects sovereign-bank public debt linkages. Our results would appear to confirm the applicability of Merton (1974)- type models extended to include market variables to the understanding of bank credit risk. 


\section{References}

Admati, A., Hellwig, M., 2013. The Bankers' New Clothes. Princeton University Press.

Alter, A., Schüler, Y.S., 2012. Credit spread interdependencies of European states and banks during the financial crisis. Journal of Banking \& Finance 36, 3444-3468.

Annaert, J., De Ceuster, M., Van Roy, P., Vespro, C., 2013. What determines Euro area bank CDS spreads? Journal of International Money and Finance 32, 444-461.

Benkert, C., 2004. Explaining credit default swap premia. Journal of Futures Markets 24, 71-92.

Bernanke, B.S., Gertler, M., 1995. Inside the black box: the credit channel of monetary policy transmission. Journal of Economic Perspectives 9, 27-48.

Blanco, R., Brennan, S., Marsh, I.W., 2005. An empirical analysis of the dynamic relation between investment-grade bonds and credit default swaps. Journal of Finance 60, 22552281.

Brewer, E., Kaufman, G., Wall, L., 2008. Bank capital ratios across countries: why do they vary? Journal of Financial Services Research 34, 177-201.

Chen, L., Lesmond, D., A., Wei, J., Z., 2007. Corporate yield spreads and bond liquidity. Journal of Finance 62, 119-149.

Chiaramonte, L, Casu, B, 2013. The determinants of bank CDS spreads: evidence from the financial crisis. European Journal of Finance 19, 861-887.

Diamond, D., Rajan, R., 2000. A theory of bank capital. Journal of Finance 55, 2431-2465.

Driessen, J., 2005. Is default event risk priced in corporate bonds? Review of Financial Studies $18,165-195$.

Duffee, G.R., 1998. The relation between Treasury yields and corporate bond yield spreads. Journal of Finance 53, 2225-2241. 
Fabozzi, F.J., Xiaolin, C., Chen, R-R., 2007. Exploring the components of credit risk in credit default swaps. Finance Research Letters 4, 10-18.

Hasan, I., Liu, L., Zhang, G., 2014. The Determinants of Global Bank Credit-Default-Swap Spreads. Fordham University Research Paper No. 2770433.

Hull, J., C., Predescu, M., White, A., 2004. The relationship between credit default swap spreads, bond yields, and credit rating announcements. Journal of Banking \& Finance 28, 27892811.

Kalemli-Özcan, S., Sorensen, B., Yesiltas , S., 2012. Leverage across firms, banks and countries. Journal of International Economics. 88, 284-298.

Kiyotaki, N., Moore, J., 1997. Credit cycles. Journal of Political Economy 105, 211-248.

Laeven, L, Valencia, F, 2012. Systemic Banking Crises Database: An Update. IMF Working Paper 12/163.

Longstaff, F.A., S., Mithal, Neis, E., 2005. Corporate yield spreads: default risk or liquidity? New evidence from the credit default swap market. Journal of Finance 60, 2213-2253.

Merton, R.C., 1974. On the pricing of corporate debt: the risk structure of interest rates. Journal of Finance 29, 449-470.

Samaniego-Medina, R., Trujillo-Ponce, A., Parrado-Martínez, P., di Pietro, F., 2016.

Determinants of bank CDS spreads in Europe. Journal of Economics and Business 86, 1-15.

Tian, S., Yang, Y., Zhang, G., 2013. Bank capital, interbank contagion, and bailout policy. Journal of Banking \& Finance 37, 2765-2778. 
Figure 1

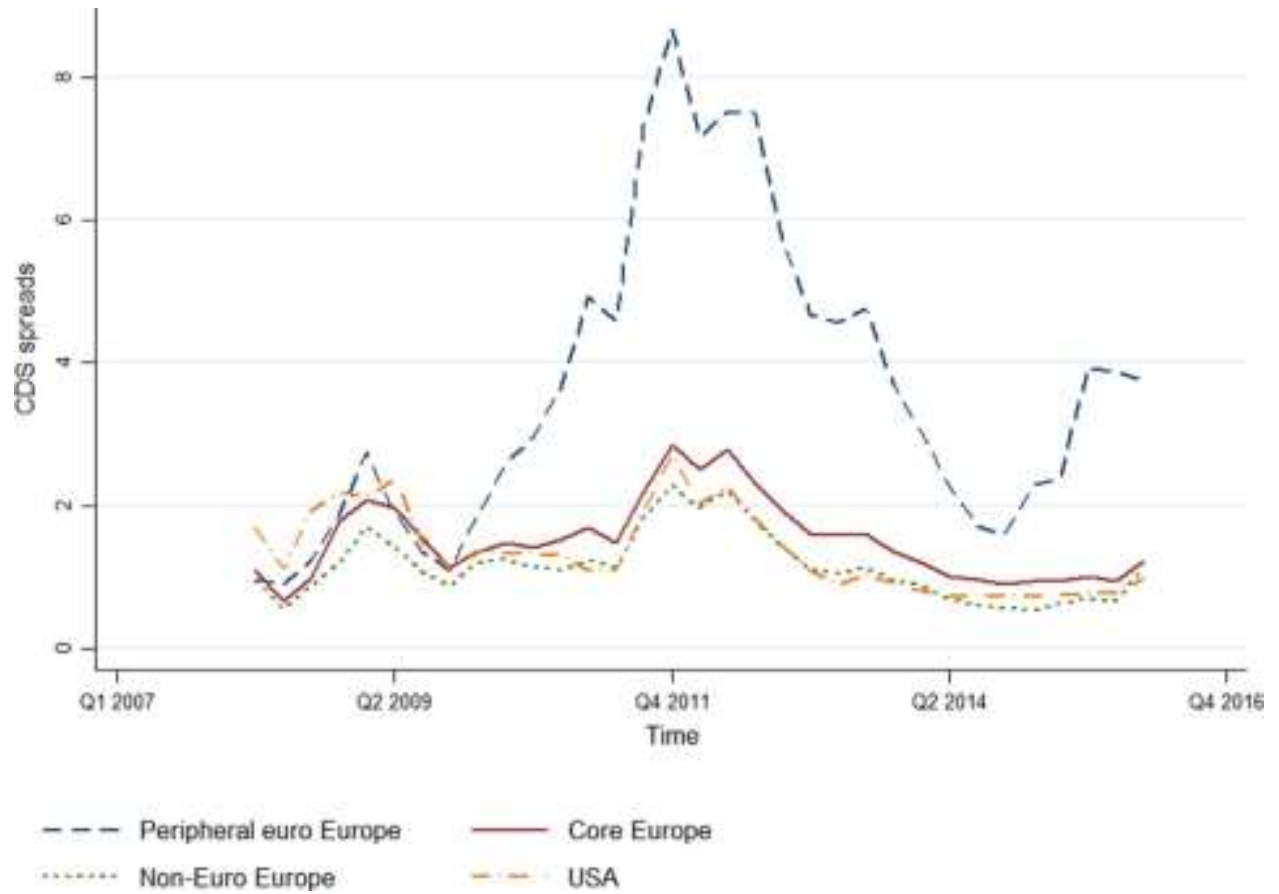




\begin{tabular}{|c|c|c|c|}
\hline \multicolumn{4}{|c|}{$\begin{array}{l}\text { Table } 1 \\
\text { Variable description, data source and expected coefficient sign }\end{array}$} \\
\hline Variable & Description & Data source & Expected sign on coefficient \\
\hline \multicolumn{4}{|l|}{ A. Balance sheet determinants } \\
\hline Capital adequacy & $\begin{array}{l}\text { Ratio of Tier } 1 \text { capital to risk- } \\
\text { weighted assets }\end{array}$ & Bankscope & - \\
\hline Leverage & $\begin{array}{l}\text { Ratio of liabilities to the sum of } \\
\text { liabilities and equity }\end{array}$ & Bankscope & + \\
\hline Non-performing loans & $\begin{array}{l}\text { Ratio of non-performing loans to } \\
\text { total assets }\end{array}$ & Bankscope & + \\
\hline Loan loss provisions & $\begin{array}{l}\text { Ratio of loan loss provisions to } \\
\text { total loans }\end{array}$ & Bankscope & + \\
\hline Bank size & Natural logarithm of total assets & Bankscope & - \\
\hline Funding stability & Ratio of deposits to total liabilities & Bankscope & - \\
\hline \multicolumn{4}{|l|}{ B. Market determinants } \\
\hline Stock market return & $\begin{array}{l}\text { S\&P } 500 \text { index for US banks; } \\
\text { Stoxx index for European banks }\end{array}$ & Datastream & - \\
\hline Stock market volatility & $\begin{array}{l}\text { The CBOE Volatility Index for US } \\
\text { bank stocks; VSTOXX index for } \\
\text { European banks }\end{array}$ & Datastream & + \\
\hline Risk free interest rate & Yield on 5-year government bonds & Datastream & - \\
\hline Term structure & $\begin{array}{l}\text { Yield on 5-year government bonds } \\
10 \text {-year government bond yield less } \\
\text { yield on } 2 \text {-year Treasury bonds }\end{array}$ & $\begin{array}{l}\text { Datastream, authors' } \\
\text { calculation }\end{array}$ & - \\
\hline Bank-specific credit risk rating & $\begin{array}{l}\text { Index ranging from } 1 \text { (Moody's } \\
\text { rating Ca or less than Ca) to } 17 \\
\text { (Moody's rating Aaa) }\end{array}$ & Datastream/Moody's & + \\
\hline Sovereign credit risk rating & $\begin{array}{l}\text { Index ranging from } 1 \text { (Moody's } \\
\text { rating Ca or less than Ca) to } 17 \\
\text { (Moody's rating Aaa) }\end{array}$ & Datastream/Moody’s & - \\
\hline
\end{tabular}




\begin{tabular}{|c|c|c|c|c|c|c|}
\hline \multicolumn{7}{|c|}{$\begin{array}{l}\text { Table } 2 \\
\text { Summary statistics for } 63 \text { European and US banks, Q1 2007-Q1 } 2016\end{array}$} \\
\hline \multicolumn{7}{|c|}{ A. CDS spreads } \\
\hline & No. of banks & Observations & Mean & Minimum & Maximum & Standard deviation \\
\hline All banks & 63 & 734 & 178.56 & 33.00 & 2646.39 & 207.93 \\
\hline Euro-core & 21 & 159 & 156.09 & 34.70 & 1375.00 & 107.67 \\
\hline Euro-periphery & 19 & 193 & 366.52 & 39.88 & 3105.00 & 414.00 \\
\hline Non-euro & 14 & 198 & 117.18 & 33.00 & 387.77 & 65.17 \\
\hline \multirow[t]{3}{*}{ USA } & 9 & 184 & 125.63 & 54.88 & 250.69 & 51.45 \\
\hline & \multicolumn{6}{|l|}{ Variable mean } \\
\hline & All banks & Euro-core & Euro-periphery & Non-euro & USA & \\
\hline \multicolumn{7}{|l|}{ B. Balance sheet determinants } \\
\hline Capital adequacy & 12.08 & 10.96 & 12.07 & 13.03 & 12.27 & \\
\hline Leverage & 93.48 & 95.46 & 92.29 & 95.73 & 89.92 & \\
\hline Non-performing loans & 2.82 & 2.39 & 6.19 & 1.30 & 1.06 & \\
\hline Loan loss provisions & 0.67 & 0.68 & 0.94 & 0.36 & 0.70 & \\
\hline Bank size & 19.87 & 19.56 & 18.98 & 20.60 & 20.41 & \\
\hline Funding stability & 56.40 & 55.11 & 59.16 & 50.55 & 61.58 & \\
\hline \multicolumn{7}{|l|}{ C. Market determinants } \\
\hline Stock market return & 5.18 & 5.66 & 5.66 & 5.66 & 5.18 & \\
\hline Stock market volatility & 26.67 & 27.55 & 27.55 & 27.55 & 21.36 & \\
\hline Risk free interest rate & 2.03 & 2.20 & 2.20 & 2.20 & 1.93 & \\
\hline Term structure & 1.75 & 1.78 & 1.78 & 1.78 & 1.73 & \\
\hline Bank-specific credit risk rating & 11.94 & 12.53 & 9.40 & 13.71 & 11.86 & \\
\hline Sovereign credit risk rating & 14.99 & 16.80 & 10.60 & 16.79 & 17.00 & \\
\hline
\end{tabular}




\begin{tabular}{|c|c|c|c|}
\hline \multicolumn{4}{|c|}{$\begin{array}{l}\text { Table } 3 \\
\text { Panel regression results: the determinants of bank CDS spreads, Q1 } 2007 \text { to Q1 } 2016\end{array}$} \\
\hline & 1 & 2 & 3 \\
\hline Dependent variable: & $C D S_{\text {it }+1 \text { week }}$ & $C D S_{i t}$ & $C D S_{i t+2 w e e k s}$ \\
\hline Capital adequacy & $\begin{array}{l}-0.045 \\
(0.093)\end{array}$ & $\begin{array}{l}-0.050 \\
(0.091)\end{array}$ & $\begin{array}{l}-0.031 \\
(0.084)\end{array}$ \\
\hline Leverage & $\begin{array}{c}0.197^{*} \\
(0.116)\end{array}$ & $\begin{array}{r}0.195^{*} \\
(0.100)\end{array}$ & $\begin{array}{r}0.189^{*} \\
(0.102)\end{array}$ \\
\hline Non-performing loans & $\begin{array}{l}0.453^{* * *} \\
(0.112)\end{array}$ & $\begin{array}{l}0.302 * * \\
(0.124)\end{array}$ & $\begin{array}{l}0.308^{* * * *} \\
(0.112)\end{array}$ \\
\hline Loan loss provisions & $\begin{array}{c}0.058 \\
(0.090) \\
\end{array}$ & $\begin{array}{c}0.056 \\
(0.076) \\
\end{array}$ & $\begin{array}{l}0.172^{* *} \\
(0.074)\end{array}$ \\
\hline Bank size & $\begin{array}{l}-1.082 * * \\
(0.514)\end{array}$ & $\begin{array}{l}-1.014 * * \\
(0.513)\end{array}$ & $\begin{array}{l}-0.984 * \\
(0.528)\end{array}$ \\
\hline Funding stability & $\begin{array}{l}-0.086^{* * *} \\
(0.011)\end{array}$ & $\begin{array}{l}-0.007 \\
(0.010)\end{array}$ & $\begin{array}{l}-0.019 * \\
(0.012)\end{array}$ \\
\hline Stock market return & $\begin{array}{l}-0.944 * * * \\
(0.472)\end{array}$ & $\begin{array}{l}-0.451^{*} \\
(0.233)\end{array}$ & $\begin{array}{l}-0.421 * * * \\
(0.145)\end{array}$ \\
\hline Stock market volatility & $\begin{array}{l}0.039 * * \\
(0.015)\end{array}$ & $\begin{array}{l}0.140 * * \\
(0.067)\end{array}$ & $\begin{array}{l}0.925 * * * \\
(0.064)\end{array}$ \\
\hline Risk free interest rate & $\begin{array}{c}0.390 \\
(0.018)\end{array}$ & $\begin{array}{c}0.022 \\
(0.015)\end{array}$ & $\begin{array}{l}0.050^{* * * *} \\
(0.019)\end{array}$ \\
\hline Term structure & $\begin{array}{l}-1.155^{* * *} \\
(0.206)\end{array}$ & $\begin{array}{l}-0.140 \\
(0.163\end{array}$ & $\begin{array}{l}-0.129 \\
(0.171)\end{array}$ \\
\hline Bank-specific credit risk rating & $\begin{array}{l}-0.312^{* * *} \\
(0.066)\end{array}$ & $\begin{array}{l}-0.835^{* * *} \\
(0.171)\end{array}$ & $\begin{array}{l}-1.147^{* * *} \\
(0.200)\end{array}$ \\
\hline Sovereign credit risk rating & $\begin{array}{l}-0.902 * * * \\
(0.126)\end{array}$ & $\begin{array}{l}-0.482 \\
(0.137)\end{array}$ & $\begin{array}{l}-0.480 \\
(0.118)\end{array}$ \\
\hline US crisis dummy & $\begin{array}{l}1.462 * * * \\
(0.278)\end{array}$ & $\begin{array}{l}1.412 * * * \\
(0.299)\end{array}$ & $\begin{array}{c}0.686^{* *} \\
(0.326)\end{array}$ \\
\hline Intercept & $\begin{array}{l}3.989 \\
(10.080)\end{array}$ & $\begin{array}{l}8.376 \\
(10.247)\end{array}$ & $\begin{array}{c}2.314 \\
(11.862) \\
\end{array}$ \\
\hline R2 & 0.289 & 0.325 & 0.259 \\
\hline Wooldridge test & 0.674 & 0.255 & 0.109 \\
\hline Fixed effects & Yes & Yes & Yes \\
\hline Bank clustering & Yes & Yes & Yes \\
\hline Observations & 734 & 734 & 734 \\
\hline \multicolumn{4}{|l|}{ Marginal contributions } \\
\hline Balance sheet determinants & $20.00 \%$ & $16.48 \%$ & $17.80 \%$ \\
\hline Market determinants & $22.31 \%$ & $3.33 \%$ & $9.48 \%$ \\
\hline US crisis dummy & $57.69 \%$ & $80.19 \%$ & $72.72 \%$ \\
\hline \multicolumn{4}{|c|}{$\begin{array}{l}\text { Robust standard errors in parenthesis below the coefficient estimates. } \\
\text { The Wooldridge test reports the p-values for the null hypothesis of no serial correlation. } \\
* * * \text { indicate statistical significance at the levels of } 1 \% \text {. } \\
* * \text { indicate statistical significance at the levels of } 5 \% \text {. } \\
* \text { indicate statistical significance at the levels of } 10 \% \text {. }\end{array}$} \\
\hline
\end{tabular}




\begin{tabular}{|c|c|c|c|c|}
\hline \multicolumn{5}{|c|}{$\begin{array}{l}\text { Table } 4 \\
\text { Panel regression results: the determinants of bank CDS spreads by geographic region }\end{array}$} \\
\hline & 1 & 2 & 3 & 4 \\
\hline Dependent variable: $C D S_{i t+1 \text { week }}$ & Euro-core & Euro-peripheral & Non-euro & USA \\
\hline Capital adequacy & $\begin{array}{l}-0.129 \\
(0.090)\end{array}$ & $\begin{array}{l}-0.315 \\
(0.236)\end{array}$ & $\begin{array}{l}-0.054 \\
(0.033)\end{array}$ & $\begin{array}{l}-0.200^{* * *} \\
(0.057)\end{array}$ \\
\hline Leverage & $\begin{array}{l}-0.273 \\
(0.384)\end{array}$ & $\begin{array}{r}0.357^{*} \\
(0.216)\end{array}$ & $\begin{array}{l}-0.065 \\
(0.110)\end{array}$ & $\begin{array}{l}0.430^{* * *} \\
(0.122)\end{array}$ \\
\hline Non-performing loans & $\begin{array}{l}-0.213 \\
(0.141)\end{array}$ & $\begin{array}{l}0.057 \\
(0.081)\end{array}$ & $\begin{array}{l}0.178 \\
(0.185)\end{array}$ & $\begin{array}{l}0.698 * * \\
(0.318)\end{array}$ \\
\hline Loan loss provisions & $\begin{array}{l}0.527 \\
(0.465)\end{array}$ & $\begin{array}{l}0.249 * * \\
(0.142)\end{array}$ & $\begin{array}{l}0.132 \\
(0.116)\end{array}$ & $\begin{array}{r}0.031^{*} \\
(0.019)\end{array}$ \\
\hline Bank size & $\begin{array}{c}0.428 \\
(1.301)\end{array}$ & $\begin{array}{l}-1.447 * * * \\
(0.282)\end{array}$ & $\begin{array}{l}-0.253 \\
(0.410)\end{array}$ & $\begin{array}{l}-1.824 * * \\
(0.837)\end{array}$ \\
\hline Funding stability & $\begin{array}{l}-0.041 * * \\
(0.019)\end{array}$ & $\begin{array}{l}-0.005 \\
(0.019)\end{array}$ & $\begin{array}{c}0.003 \\
(0.005)\end{array}$ & $\begin{array}{l}-0.036^{*} \\
(0.019) \\
\end{array}$ \\
\hline Stock market return & $\begin{array}{l}-1.861^{*} \\
(0.999)\end{array}$ & $\begin{array}{c}0.728 \\
(1.248)\end{array}$ & $\begin{array}{l}-0.897 * * * \\
(0.185)\end{array}$ & $\begin{array}{l}-0.984 * * \\
(0.456)\end{array}$ \\
\hline Stock market volatility & $\begin{array}{c}0.002 \\
(0.015)\end{array}$ & $\begin{array}{l}0.159 * * * \\
(0.058)\end{array}$ & $\begin{array}{c}0.028^{*} \\
(0.016)\end{array}$ & $\begin{array}{c}0.011^{*} \\
(0.006)\end{array}$ \\
\hline Risk free interest rate & $\begin{array}{c}0.701 \\
(0.446)\end{array}$ & $\begin{array}{l}-0.724 * \\
(0.401)\end{array}$ & $\begin{array}{c}0.134 \\
(0.122)\end{array}$ & $\begin{array}{c}0.164 \\
(0.363)\end{array}$ \\
\hline Term structure & $\begin{array}{l}-0.444 * * \\
(0.190)\end{array}$ & $\begin{array}{l}-0.123 \\
(0.590)\end{array}$ & $\begin{array}{l}-0.273^{* *} \\
(0.128)\end{array}$ & $\begin{array}{l}-0.811^{* * *} \\
(0.130)\end{array}$ \\
\hline Bank-specific credit risk rating & $\begin{array}{l}-0.205^{* *} \\
(0.090)\end{array}$ & $\begin{array}{l}-0.252^{* *} \\
(0.099)\end{array}$ & $\begin{array}{c}0.030 \\
(0.111)\end{array}$ & $\begin{array}{l}-0.388 * * * \\
(0.130)\end{array}$ \\
\hline Sovereign credit risk rating & $\begin{array}{c}0.371 \\
(0.302)\end{array}$ & $\begin{array}{l}-0.943^{* *} \\
(0.368)\end{array}$ & $\begin{array}{l}-0.042 \\
(0.278)\end{array}$ & \\
\hline US crisis dummy & $\begin{array}{l}1.299^{* * *} \\
(0.466)\end{array}$ & $\begin{array}{l}-0.120 \\
(0.553)\end{array}$ & $\begin{array}{l}0.913^{* * *} \\
(0.217)\end{array}$ & $\begin{array}{l}1.479 * * * \\
(0.363)\end{array}$ \\
\hline Intercept & $\begin{array}{l}23.517 \\
(21.034)\end{array}$ & $\begin{array}{l}2.362 \\
(35.168)\end{array}$ & $\begin{array}{c}3.243 \\
(9.707)\end{array}$ & $\begin{array}{l}7.689 \\
(9.454)\end{array}$ \\
\hline R2 & 0.318 & 0.496 & 0.565 & 0.398 \\
\hline Wooldridge test & 0.355 & 0.905 & 0.456 & 0.246 \\
\hline Fixed effects & Yes & Yes & Yes & Yes \\
\hline Bank clustering & Yes & Yes & Yes & Yes \\
\hline Observations & 159 & 193 & 198 & 184 \\
\hline Marginal contributions & & & & \\
\hline Balance sheet determinants & $33.20 \%$ & $15.01 \%$ & $13.87 \%$ & $63.27 \%$ \\
\hline Market determinants & $24.01 \%$ & $22.99 \%$ & $46.11 \%$ & $6.53 \%$ \\
\hline US crisis dummy & $42.79 \%$ & $62.00 \%$ & $40.02 \%$ & $30.20 \%$ \\
\hline $\begin{array}{l}\text { Robust standard errors in parenthesi } \\
\text { The Wooldridge test reports the p-va } \\
* * * \text { indicate statistical significance a } \\
* * \text { indicate statistical significance at } \\
* \text { indicate statistical significance at } t\end{array}$ & $\begin{array}{l}\text { below the cc } \\
\text { ues for the } n \\
\text { the levels of } \\
\text { he levels of } \\
\text { e levels of } 1\end{array}$ & $\begin{array}{l}\text { t estimates. } \\
\text { thesis of no ser }\end{array}$ & correlation. & \\
\hline
\end{tabular}

